\title{
Expression of Nonmetric Dental Traits in Western European Neanderthals
}

\author{
Frank L'Engle Williams ${ }^{1,{ }^{*}}$, Rebecca L. George ${ }^{2}$, Marie-Antoinette de Lumley ${ }^{3,4}$, \\ Gaël Becam ${ }^{3, *}$ \\ ${ }^{1}$ Department of Anthropology, Georgia State University, Atlanta, GA 30303 \\ ${ }^{2}$ Department of Anthropology, University of Nevada, Reno, NV 89557 \\ ${ }^{3}$ UMR 7194 CNRS, HNHP, MNHN/UPVD/CERP de Tautavel, France
}

Keywords: Engis 2, Hortus, Malarnaud, Montmaurin, Pech de l'Azé 1, Roc de Marsal , Scladina 1-4A

ABSTRACT Neanderthals of Western Europe lived across distinct ecogeographic zones from Marine Isotope Stage 7 to 3. Differences in dental morphology from seven Western European sites are compared in terms of ecogeography and chronology.

Neanderthals $(n=12)$ along a north-south gradient were examined. These included the Meuse River Basin of Belgium (Engis 2 and Scladina 1-4A ), Southwest France (Pech de l'Azé 1 and Roc de Marsal), the Pyrenees (Malarnaud and Montmaurin), and the Mediterranean (Hortus). Montmaurin is the oldest, followed by Scladina 1-4A and Malarnaud, whereas the others are younger.

Dental casts were prepared from Neanderthal permanent and deciduous dentition. These were described and scored, according to the ASUDAS. Comparisons of dental traits with respect to ecogeographic regions and chronological categories were constructed.

Unusual dental features observed include the anterior fovea, entoconulid, metaconulid, and Carabelli's cusp. Dental traits that distinguish ecogeographic regions are the expression of the $\mathrm{M}^{1}$ hypocone and metaconule, whereas the hypoconulid and Carabelli's cusp separate chronological categories. Differences are present for the entoconulid and metaconulid in both comparisons.

Neither chronology nor ecogeography fully explains the results. Similarities in dental traits exist between Roc de Marsal, Pech de l'Azé 1 and Engis 2, and secondarily within the Hortus assemblage.

Neanderthals are known for their taurodont molar roots, shovel-shaped incisors as well as the expression of dental morphological features that are relatively uncommon in modern humans (Patte, 1959; Zubov, 1992; Bailey, 2000, 2002, 2004, 2006; Hublin et al., 2012). However, differences may also exist between Neanderthal sites, irrespective of their relationship to modern humans. Small family groups and a relatively limited degree of genetic variation may have characterized Neanderthals (Lalueza-Fox et al., 2011; Kelso and Prüfer, 2014). Using observations of dental morphology from a relatively large sample of Neanderthals $(n=12)$ from Western Europe, we examine whether ecogeography or chronology (or neither) more adequately accounts for the variation observed. Six individuals from a single site (Hortus) allow for a comparison of within and between fossil assemblages to investigate the expression of nonmetric dental traits. We also note which features are commonly expressed or are unusual in this sample of Neanderthals.

NEANDERTHALS OF WESTERN EUROPE Several regions of Western Europe appear to have been core areas of Neanderthal habitation, even when colder conditions prevailed (Hublin and Roebroeks, 2009). Neanderthal tools, faunal remains, and osteological remnants in these regions are situated primarily between Marine Isotope Stages (MIS) 5 to 3 (Soressi et al., 2007), and are evidenced as far north as Belgium to the terminus of MIS 3 (Würm II) at about 36 kya as demonstrated by the remains from Spy cave (Semal et al., 2005, 2009; Toussaint et al., 2011; Pirson et al., 2014). The earliest Neanderthal discovered in 18291830, Engis 2, is probably also from MIS 3 based on associated Mousterian artifacts and fauna (Twiesselmann, 1971), although it could be younger, between $26,830 \pm 430$ and $30,460 \pm 210$ years BP (Toussaint et al., 2011). Scladina 1-4A, also located along the Meuse River Basin of Belgium, has been dated to MIS 5 or earlier (Pirson et al., 2014), attest-

*Correspondence to:

Dr. Frank L'Engle Williams, Department of Anthropology, Georgia State University e-mail: frankwilliams@gsu.edu Dr. Gaël Becam, UMR 7194 CNRS, HNHP, MNHN/ UPVD/CERP de Tautavel, France gael.becam@cerptautavel.com 
ing to the probable recolonization of the Meuse River Basin of Belgium after the climate deterioration of MIS 4 (Hublin and Roebroeks, 2009; Toussaint et al., 2011; Di Modica et al., 2016). Scladina 1-4A is probably between 80 -87 kya based on chronostratigraphic analyses using the Greenland Record as context, although it could be as old as 127 kya (Pirson et al., 2014; Toussaint et al., 2014).

Additional Neanderthal sites in Western Europe include those from the Perigord such as Roc de Marsal, which has been dated to 60-70 kya and is close to the terminus of MIS 4 (Guérin et al., 2012), and Pech de l'Azé 1 and has been dated to 51-41 kya (Soressi et al., 2007). Further south along the slopes of the northern Pyrenees in the Ariégeoises region is the site of Malarnaud, which is suggested to be from the Riss-Würm interval (MIS 5). Also from the northern Pyrenees region is Montmaurin cave which has been dated to MIS 7 (Crégut-Bonnoure et al., 2010).

The Mediterranean region may have been at least partially isolated from the Pyrenees and other areas by glacier formations in the Massif Central and in particular, the Languedoc Mountains. Between the Mediterranean coast and the piedmont region south of this glaciation is the cave of Hortus yielding between 20 and 36 Neanderthal children and adults, and dated to MIS 3 (Würm II) (Lumley, 1973, 1976). Six of the Hortus remains are examined here, including Hortus II, Hortus IV, Hortus V, Hortus VI, Hortus VIII, and Hortus XI.

Dental traits in these disparate ecogeographic zones may vary as a function of distance. Alternatively, individuals may differ with respect to time period, whereby older sites (Montmaurin, Scladina 1-4A and Malarnaud) may be distinct from the younger sites of Engis 2, Hortus,
Pech de l'Azé 1 and Roc de Marsal. The explanatory power of these models is explored here with respect to the dental morphology of Western European Neanderthals.

\section{MATERIALS AND METHODS}

A total of 12 Neanderthals from seven sites are sampled in this study. Two individuals are represented solely by deciduous molars, two preserve both deciduous and permanent teeth and seven include only the permanent molars. Table 1 lists the teeth examined by site and individual.

A macroscopic investigation of the original fossil dentition was conducted by the first author (FLW) at the Musée de l'Homme, the Centre Européen de Recherches Préhistoriques de Tautavel, the Musée national de Préhistoire, Les Eyzies-de-Tayac, the Universite de Liège, and the Scladina Cave Archaeological Centre. The fossil teeth and Scladina resin casts were molded using polyvinylsiloxane (Coltène-Whaledent). Dental casts were created from the dental molds using centrifuged epoxy resin and hardener (Buehler) at the Bioarchaeology Lab of Georgia State University, and were examined by one observer (RLG) using the Arizona State University Dental Anthropology System (ASUDAS; Turner et al., 1991) and a nonmetric data scoring sheet developed by R.L. George. The dental scoring system of the ASUDAS is a replicable method in which the teeth are scored at different intervals to account for the expression of a feature. Deciduous anterior teeth were scored according to the Hanihara (1961) standards for deciduous dentition. The macroscopic observations of the original Neanderthal fossil dentition were included where necessary. However, only traits visible on the dental casts were scored and recorded using

Table 1. Neanderthal dentition used in morphology descriptions.

\begin{tabular}{|c|c|c|c|}
\hline Fossil & Teeth examined & Ecogeography & Chronology \\
\hline Engis 2 & $\mathrm{di}^{1}, \mathrm{dc}, \mathrm{dm}^{1}, \mathrm{dm}^{2}, \mathrm{dm}_{1}, \mathrm{dm}_{2}, \mathrm{M}_{1}$ & Meuse River Basin (Belgium) & Younger \\
\hline Hortus II & $\mathrm{M}_{1}$ & Mediterranean (France) & Younger \\
\hline Hortus IV & $\mathrm{M}_{1}, \mathrm{M}_{2}$ & Mediterranean (France) & Younger \\
\hline Hortus V & $\mathrm{M}_{1}, \mathrm{M}_{2}, \mathrm{M}_{3}$ & Mediterranean (France) & Younger \\
\hline Hortus VI & $\mathrm{M}_{3}$ & Mediterranean (France) & Younger \\
\hline Hortus VIII & $\mathrm{M}^{1}$ & Mediterranean (France) & Younger \\
\hline Hortus XI & $\mathrm{M}^{3}$ & Mediterranean (France) & Younger \\
\hline Malarnaud & $\mathrm{M}_{1}$ & Pyrenees (France) & Older \\
\hline Montmaurin & $\mathrm{M}_{1}, \mathrm{M}_{2}, \mathrm{M}_{3}$ & Pyrenees (France) & Older \\
\hline Pech de l'Azé & $\mathrm{dm}^{1}, \mathrm{dm}^{2}, \mathrm{dm}_{1}, \mathrm{dm}_{2}$ & Southwest France & Younger \\
\hline Roc de Marsal & $\mathrm{dm}^{1}, \mathrm{dm}^{2}, \mathrm{dm}_{1}, \mathrm{dm}_{2}$ & Southwest France & Younger \\
\hline Scladina 4A & $\mathrm{dm}^{1}, \mathrm{dm}^{2}, \mathrm{M}^{2}, \mathrm{M}_{1}, \mathrm{M}_{2}$ & Meuse River Basin (Belgium) & Older \\
\hline
\end{tabular}


the ASUDAS.

\section{RESULTS}

Engis 2

Engis 2 preserves a relatively complete immature calvarium, isolated maxilla and several teeth, and has been aged to between four and five years (Tillier, 1983; MinughPurvis, 1988; Toussaint et al., 2011; Williams, 2013; Williams and Cofran, 2016). The dental remains of Engis 2 examined here include the left maxillary deciduous incisors ( $\mathrm{di}^{1}$ and $\left.\mathrm{di}^{2}\right)$, which are shoveled (Hanihara grade 3 ), and a right maxillary deciduous canine characterized by a weakly developed tuberculum dentale (Hanihara grade 5). The right maxillary deciduous molars $\left(\mathrm{dm}^{1}\right.$ and $\left.\mathrm{dm}^{2}\right)$ are described as well as the right mandibular deciduous first molar $\left(\mathrm{dm}_{1}\right)$ and right permanent first molar $\left(\mathrm{M}_{1}\right)$.

The right maxillary deciduous first molar $\left(\mathrm{dm}^{1}\right)$ exhibits small wear facets on the cusp tips, although much of the original morphology is preserved. There are a total of five cusps and the metacone can be described as only weakly developed (ASUDAS grade 3). Similarly, the hypocone is also small (ASUDAS grade 3 ) on $\mathrm{dm}^{1}$.

The right maxillary deciduous molar $\left(\mathrm{dm}^{2}\right)$ has a lack of substantial attrition. On $\mathrm{dm}^{2}$ there are four cusps, and the metacone and hypocone are visibly larger than on $\mathrm{dm}^{1}$ (ASUDAS grade 4). A small, but noticeable Carabelli's trait can be observed on the second deciduous molar $\left(\mathrm{dm}^{2}\right)$. However, it is not an independent cusp and its distal border does not contact the lingual groove between the protocone and the hypocone (ASUDAS grade 5).

The right mandibular deciduous second molar $\left(\mathrm{dm}_{2}\right)$ exhibits a well-developed anterior fovea which is bordered by a pronounced mesial margin (ASUDAS grade 4 ). The deciduous second molar $\left(\mathrm{dm}_{2}\right)$ has five cusps inclusive of a prominent hypoconulid (ASUDAS grade 5). Furthermore, a rather large metaconulid can also be observed within the lingual groove between the metaconid and entoconid (ASUDAS grade 4) on $\mathrm{dm}_{2}$. Two large roots are present.

The lower right first permanent molar $\left(\mathrm{M}_{1}\right)$ was probably unerupted or in the process of eruption given the absence of substantial root development (1-2 $\mathrm{mm}$ in length) and the virtual lack of attrition with the possible exception of a tiny wear facet on the metaconid. The right permanent first molar $\left(\mathrm{M}_{1}\right)$ of Engis 2 has six cusps with a weakly developed hypoconulid (ASUDAS grade 1). Lingual to the hypoconulid, a small entoconulid, or sextum tuberculum, is represented as a second lingual groove (ASUDAS grade 1). Furthermore, a small, but noticeable metaconulid exists within the lingual groove between the metaconid and the entoconid (ASUDAS grade 2). The groove pattern on the permanent first molar $\left(\mathrm{M}_{1}\right)$ can be described as conforming to the " $Y$ " pattern. A weakly developed protostylid can be observed as a small pit on the buccal surface of the protoconid (ASUDAS grade 1).

\section{Hortus II}

Hortus II, shown in Figure 1, is represented by right and left mandibular permanent first molars and has been aged to 7-8 years (Lumley, 1973). Hortus II is the accompanying lower jaw of the maxilla identified as Hortus III (Lumley, 1973; Minugh-Purvis, 1988). There is only minimal to moderate wear on the permanent first molars $\left(\mathrm{M}_{1}\right)$. The left first molar $\left(\mathrm{M}_{1}\right)$ of Hortus II (1262) preserves an anterior fovea (ASUDAS grade 3) (Lumley, 1973). The protoconid is large, pointed and separated from the hypoconid by a large buccal groove. A large, but short distobuccal groove separates the hypoconid and hypoconulid (Lumley 1973). Similarly, the lingual cusps are separated by a large lingual groove.

The groove pattern of the first molar $\left(\mathrm{M}_{1}\right)$ can be characterized as exhibiting a " $Y$ " form. The medial ridge of the metaconid is deflected distally, although it does not approach the entoconid in size (ASUDAS grade 2). A small, well-

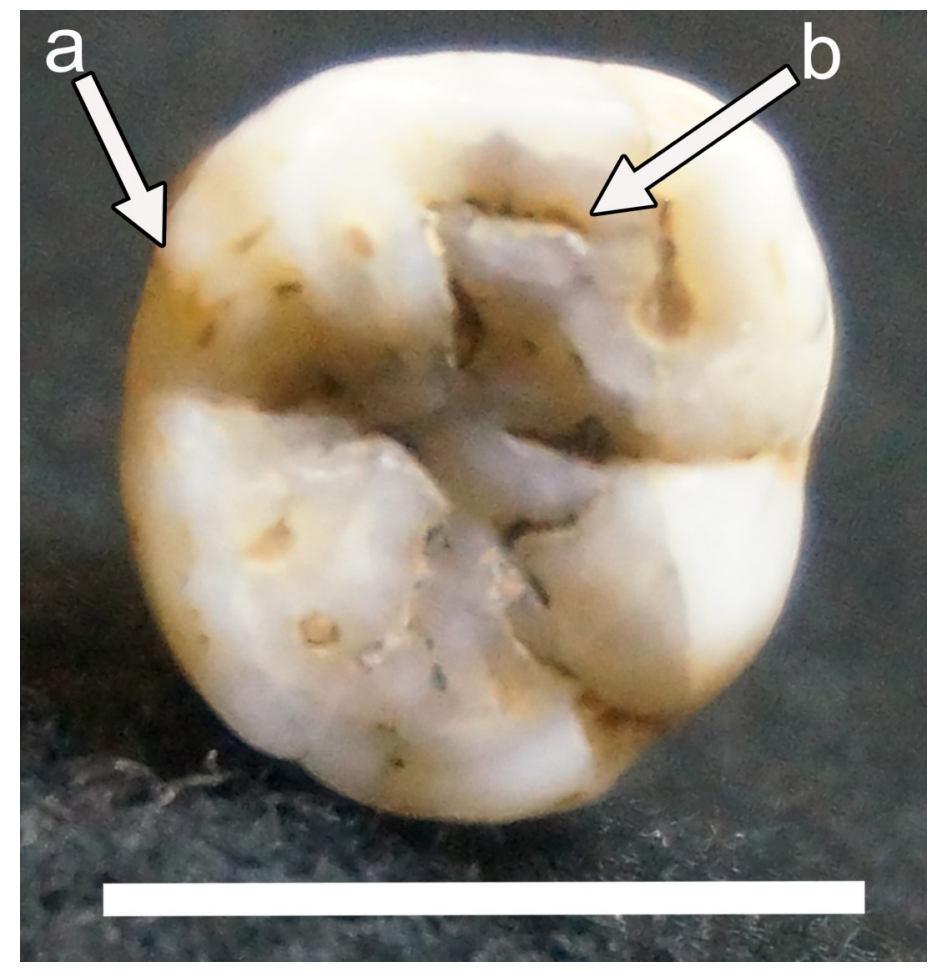

Figure 1. On the right mandibular permanent first molar $\left(\mathrm{M}_{1}\right)$ of Hortus II, a number of dental features can be observed, such as a metaconulid (a) and an anterior fovea (b).

developed metaconulid is evident (ASUDAS grade 2) (see Fig. 1).

\section{Hortus IV}

Hortus IV consists of a mandibular corpus and the inferior ascending ramus of a young adult aged 18-25 years (Lumley, 1973). Hortus IV preserves the left permanent first and second molars $\left(\mathrm{M}_{1}\right.$ and $\left.\mathrm{M}_{2}\right)$ and the right permanent second incisor $\left(\mathrm{I}_{2}\right)$, canine $(\mathrm{C})$ and first and second molars $\left(\mathrm{M}_{1}\right.$ and $\left.\mathrm{M}_{2}\right)$ in situ. The corpus is badly damaged, but the teeth are well preserved and only minimally worn. Heavier wear facets exist along the buccal occlusal surface 
of both molar rows in contrast to the lingual surfaces (Lumley, 1973).

An anterior fovea exists on all the molars (Fig. 2; Lumley, 1973). On the right permanent first molar, the anterior fovea is represented as a large and elongated groove distal to a pronounced mesial ridge (ASUDAS grade 4) (see Fig. 2). The same could be said for the left permanent second molar $\left(\mathrm{M}_{2}\right)$. However, the right permanent second molar $\left(\mathrm{M}_{2}\right)$ exhibits a slightly less elongated anterior fovea than its antimere (ASUDAS grade 3 ). The groove pattern of the right permanent second molar $\left(\mathrm{M}_{2}\right)$ evidences an " $\mathrm{X}$ " classification. On the second molars $\left(\mathrm{M}_{2}\right)$, a total of six cusps can be observed and a mid-trigonid crest connects the distal borders of the protoconid and metaconid (ASUDAS grade 1). The buccal surface of the protoconid of the right second molar $\left(\mathrm{M}_{2}\right)$ exhibits a small protostylid (ASUDAS grade 1). A prominent hypoconulid can be found on the molars (ASUDAS grade 4$)$, although on the right second molar $\left(\mathrm{M}_{2}\right)$ it is smaller (ASUDAS grade 3). An entoconulid can be observed lingual to the hypoconulid on the second molars $\left(\mathrm{M}_{2}\right)$; on the right side, the two cuspules are similar in size (ASUDAS grade 3) (see Fig. 2). On the left second molar $\left(\mathrm{M}_{2}\right)$, the entoconulid is somewhat smaller than the hypoconulid (ASUDAS grade 1). A small metaconulid is evident within the lingual groove between the metaconid and the entoconid on the first and second molars $\left(\mathrm{M}_{1}\right.$ and $\left.\mathrm{M}_{2}\right)$ (ASUDAS grade 2).

\section{Hortus $V$}

There are several isolated teeth associated with Hortus $\mathrm{V}$, and the age has been estimated to be $18-25$ years (Lumley, 1973). The left (730) and right (988) permanent first molars $\left(\mathrm{M}_{1}\right)$ exhibit moderate wear, heavier on the buccal than on the lingual cusps (Lumley, 1973) and dentine exposures can be observed. On the right (988), the metaconid is rather large and pyramidal. The hypoconulid is positioned buccally and distally. Five cusps are visible on the left (730) first molar $\left(\mathrm{M}_{1}\right)$ and a small protostylid is evident within the buccal groove separating the protoconid and the hypoconid (ASUDAS grade 1). A welldeveloped hypoconulid is visible on the first molars $\left(\mathrm{M}_{1}\right)$, although it is larger on the right (ASUDAS

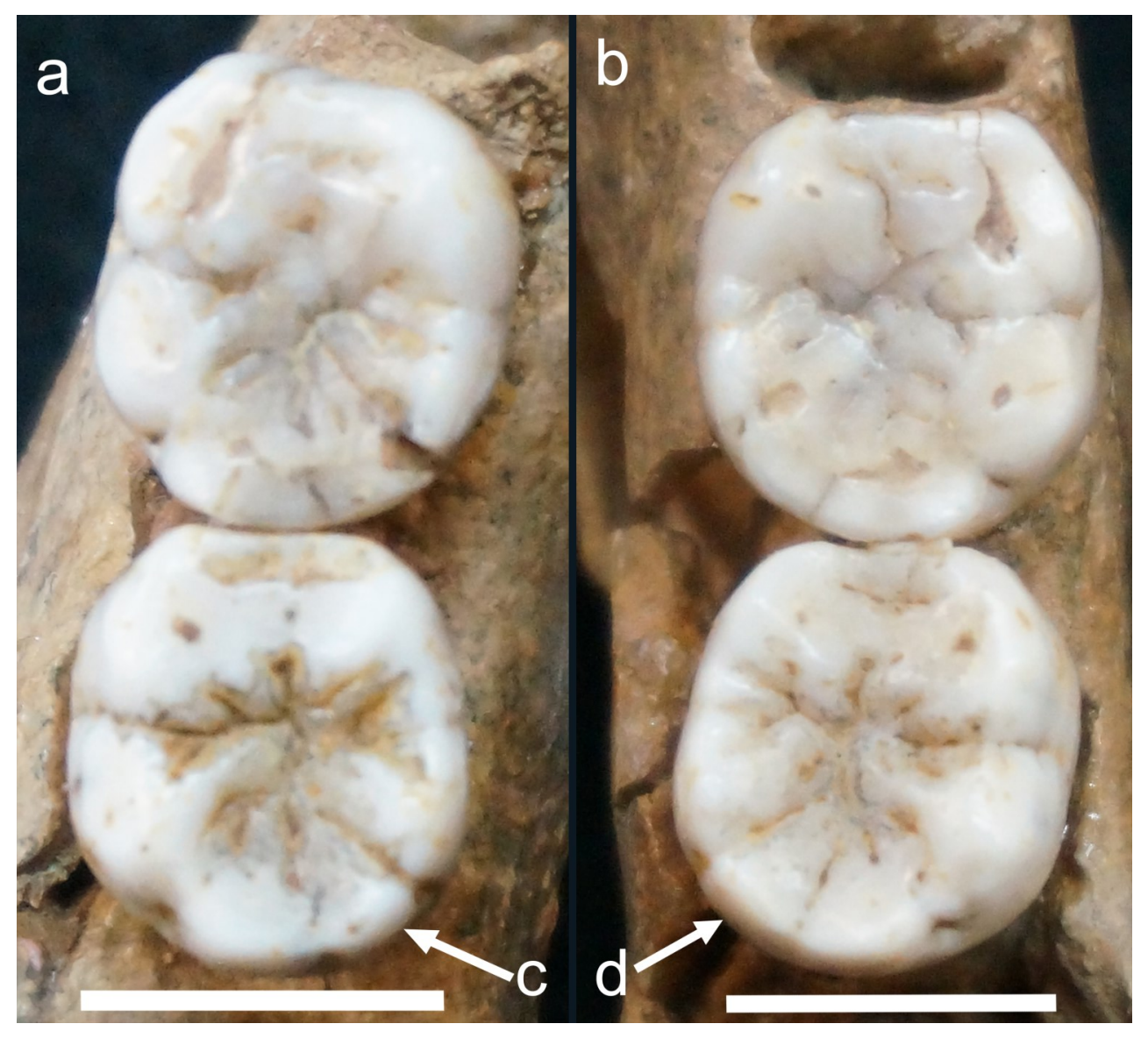

Figure 2. The left (a) and right (b) mandibular permanent first and second molars $\left(\mathrm{M}_{1}\right.$ and $\left.\mathrm{M}_{2}\right)$ of Hortus IV exhibit well-demarcated anterior foveae. Variation in the development of the entoconulid (Cusp 6) is evident such that it is comparatively smaller vis-à-vis the hypoconulid on the left (c) compared to the relative size of the entoconulid on the right (d) permanent second molars $\left(\mathrm{M}_{2}\right)$. 
grade 3) than on the left (ASUDAS grade 2).

The left (693) second molar $\left(\mathrm{M}_{2}\right)$ exhibits less attrition than the first molars $\left(\mathrm{M}_{1}\right)$. Taurodont roots are present and the mesial ones are joined together as are the distal ones (Lumley, 1973). A small metaconulid is nestled within the lingual groove between the metaconid and the entoconid (ASUDAS grade 2 ), which is unusual on a permanent second molar (Turner et al., 1991).

The right (796) and left (695) third molars $\left(\mathrm{M}_{3}\right)$ present a well preserved and complex morphology. A prominent anterior fovea can be observed on the right (796) third molar $\left(\mathrm{M}_{3}\right)$, and it is positioned rather mesially (ASUDAS grade 4). A slightly smaller anterior fovea is evident on the left (695) third molar $\left(\mathrm{M}_{3}\right)$ (ASUDAS grade 3). The right (796) third molar $\left(\mathrm{M}_{3}\right)$ preserves a groove pattern whereby a " + " classification is evident. There are six cusps on both third molars $\left(\mathrm{M}_{3}\right)$ and a mid-trigonid crest can be observed (ASUDAS grade 1) on the right (796) third molar $\left(\mathrm{M}_{3}\right)$. A hypoconulid exists on both third molars $\left(\mathrm{M}_{3}\right)$, and on the left (695) it is bifurcated and much larger (ASUDAS grade 5) than on the right (796) (ASUDAS grade 3). Both third molars exhibit an entoconulid, albeit the expression varies, such that the left (695) expression (ASUDAS grade 2) is more pronounced than the right (796) (ASUDAS grade 1$)$. Both third molars $\left(\mathrm{M}_{3}\right)$ also exhibit a pronounced metaconulid (ASUDAS grade 2) which is rare for this dental element (Turner et al., 1991).

\section{Hortus VI}

Hortus VI is represented by a left mandibular third molar $\left(\mathrm{M}_{3}\right)$ from a young adult estimated to be 22-30 years (Lumley, 1973). Much of the original morphology is preserved (Lumley, 1973). An anterior fovea is present and well-defined (ASUDAS grade 3) (Lumley, 1973). A complex morphology characterizes the occlusal surface, and there are a total of six cusps, the first four of which are in close proximity to one another corresponding to the "+" classification. A weak protostylid is represented as a small fovea within the buccal groove between the protoconid and hypoconid (ASUDAS grade 1), although it is closer to the superior buccal surface of the hypoconid. A moderately sized hypoconulid is evident (ASUDAS grade 3) as is an entoconulid, represented as a small fovea on the distal edge of the occlusal surface (ASUDAS grade 3). The hypoconulid and entoconulid are similarly-sized.

\section{Hortus VIII}

Hortus VIII is a well-preserved right maxillary permanent first molar $\left(\mathrm{M}^{1}\right)$ which has been aged to 2634 years (Lumley, 1973). The tooth is somewhat tri- angular. A prominent metacone exists (ASUDAS grade 5) that rivals the size of the stronglypronounced hypocone (ASUDAS grade 5), and a large distal groove separates the two.

Hortus XI

The right maxillary permanent third molar $\left(\mathrm{M}^{3}\right)$ of Hortus XI has been aged to 45-50 years (Lumley, 1973). The tooth is rectangular in shape. Striations on the occlusal, buccal, and mesial surfaces may possibly derive from paramasticatory behavior (Lumley, 1973). Much of the surface morphology has been destroyed and dentine exposures are evident on the mesial cusps. The metacone is rather small in comparison (ASUDAS grade 3). A weakly developed parastyle is evidenced as a fovea lodged within the buccal groove between the paracone and metacone (ASUDAS grade 1).

\section{Malarnaud}

Malarnaud preserves a right permanent first molar $\left(\mathrm{M}_{1}\right)$ in situ and crypts for all other permanent teeth are visible, with the exception of the left third molar crown $\left(\mathrm{M}_{3}\right)$; the right third molar $\left(\mathrm{M}_{3}\right)$ crown can be partially observed deeply embedded within its crypt, and thus far from eruption. Malarnaud has been aged to around 14 years (Petite-Marie et al., 1971), but may be younger given the minimal wear on the right first permanent molar $\left(\mathrm{M}_{1}\right)$. A welldeveloped anterior fovea is present (ASUDAS grade 3). A mid-trigonid crest is evident between the protoconid and the metaconid (ASUDAS grade 1). The cusp number is five. A deflecting wrinkle is present (ASUDAS grade 1). A buccal groove between the protoconid and metaconid can be observed (ASUDAS grade 4), although the feature does not approach the development of a protostylid with a free apex.

\section{Montmaurin}

This young adult is represented by a nearly complete mandibular corpus and has right and left permanent molars rows $\left(\mathrm{M}_{1}-\mathrm{M}_{3}\right)$ in pristine condition, in situ, with minimal wear. The wear facets are most pronounced on the left first molar $\left(\mathrm{M}_{1}\right)$ buccal cusps, followed by those on the right antimere. The anterior dentition and premolars are represented by crypts. A clearly demarcated anterior fovea is evident on all three molars, although on the first and second molars $\left(\mathrm{M}_{1}\right.$ and $\left.\mathrm{M}_{2}\right)$ it is larger (ASUDAS grade 2), in comparison to the third molar $\left(\mathrm{M}_{3}\right)$ (ASUDAS grade 1) (Fig. 3). The anterior fovea is accentuated further by a strongly developed midtrigonid crest (ASUDAS grade 1) on the right and left first and second molars ( $\mathrm{M}_{1}$ and $\left.\mathrm{M}_{2}\right)$, and on the left third molar $\left(\mathrm{M}_{3}\right)$. The morphology of all the mo- 
lars is complex, particularly the third molars $\left(\mathrm{M}_{3}\right)$, which can be described as crenulated. On the right first molar $\left(\mathrm{M}_{1}\right)$, the groove pattern corresponds to the " $Y$ " configuration. On the left second molar $\left(\mathrm{M}_{2}\right)$, a " + " classification is evident, whereas on the right antimere, only the protoconid and entoconid are in contact indicative of the " $X$ " groove pattern. There are five cusps on the first and second molars $\left(\mathrm{M}_{2}\right.$ and $\mathrm{M}_{2}$ ) and the left third molar $\left(\mathrm{M}_{3}\right)$, and four cusps on the right third molar $\left(\mathrm{M}_{3}\right)$. A pit can be observed on the buccal surface of the protoconid of the right first molar $\left(\mathrm{M}_{1}\right)$ (ASUDAS grade 1$)$, and is expressed as a more pronounced groove that curves distally on the buccal surface of the protoconid of the right second molar $\left(\mathrm{M}_{2}\right)$ (ASUDAS grade 2), though, neither can be described as a true protostylid. The hypoconulid can be characterized as large (ASUDAS grade 5), at least on the left first molar $\left(\mathrm{M}_{1}\right)$, and, though it is present on the left second and third molars $\left(\mathrm{M}_{2}\right.$ and $\left.\mathrm{M}_{3}\right)$, it is much smaller (ASUDAS grade 1). The molars on the right each exhibit a smaller hypoconulid compared to their counterparts on the left.

\section{Pech de l'Azé I}

The remains of Pech de l'Azé I include a nearly complete cranium and mandible of a young child that has been aged to between 2.5 and 3 years (Heim, 1976; Minugh-Purvis, 1988; Williams, 2013; Williams and Cofran, 2016). All of the deciduous teeth are fully erupted, although, the maxillary lateral incisors are missing postmortem. Dental attrition is minimal such that the deciduous molars preserve much of the original occlusal morphology.

Both of the maxillary deciduous first molars $\left(\mathrm{dm}^{1}\right)$ exhibit four cusps (ASUDAS grade 4$)$. The right and left deciduous first molars $\left(\mathrm{dm}^{1}\right)$ exhibit a relatively small metacone, although, a free apex is present (ASUDAS grade 3). The hypocone is weakly developed and is represented as a small ridge on the distobuccal aspect of the deciduous first molars $\left(\mathrm{dm}^{1}\right)$ on both sides (ASUDAS grade 1).

On the deciduous second molars $\left(\mathrm{dm}^{2}\right)$, five cusps are present. In comparison to the deciduous first molars $\left(\mathrm{dm}^{1}\right)$, the metacone is quite large on the second molars $\left(\mathrm{dm}^{2}\right)$ (ASUDAS grade 4$)$. The hypocone is much larger on the deciduous second molars $\left(\mathrm{dm}^{2}\right)$ compared to those expressed on the first molars $\left(\mathrm{dm}^{1}\right)$. However, the left deciduous second molar $\left(\mathrm{dm}^{2}\right)$ expresses a large hypocone (ASUDAS grade 4), while on the right antimere it is slightly smaller (ASUDAS grade 3). A prominent Carabelli's trait is present on the deciduous second molars $\left(\mathrm{dm}^{2}\right)$ as an independent cusp with a free apex (ASUDAS grade 7) (Fig. 4). A weak metaconule is present within the distal groove separating the hypocone and metacone on both deciduous second molars $\left(\mathrm{dm}^{2}\right)$, although it is somewhat larger on the left (ASUDAS grade 2) than on the right (ASUDAS grade 1).

The mandible of Pech de l'Azé 1 is remarkably complete, although only on the right side are the teeth well preserved. The deciduous teeth are fully erupted with minimal attrition. The permanent first molar crown $\left(\mathrm{M}_{1}\right)$ can be observed deeply in its crypt and the interior occlusal surface of the crown is complex.

On the right deciduous first molar $\left(\mathrm{dm}_{1}\right)$ of Pech de l'Azé 1, an elongated and pronounced anterior fovea is evident, bordered by a prominent mesial ridge (ASUDAS grade 4). Four cusps can be observed on the right deciduous first molar $\left(\mathrm{dm}_{1}\right)$.

The right deciduous second molar $\left(\mathrm{dm}_{2}\right)$ exhibits a protostylid, although it is only weakly developed, consisting primarily of a raised fovea that is low and flat with a small indentation that is deep, nestled

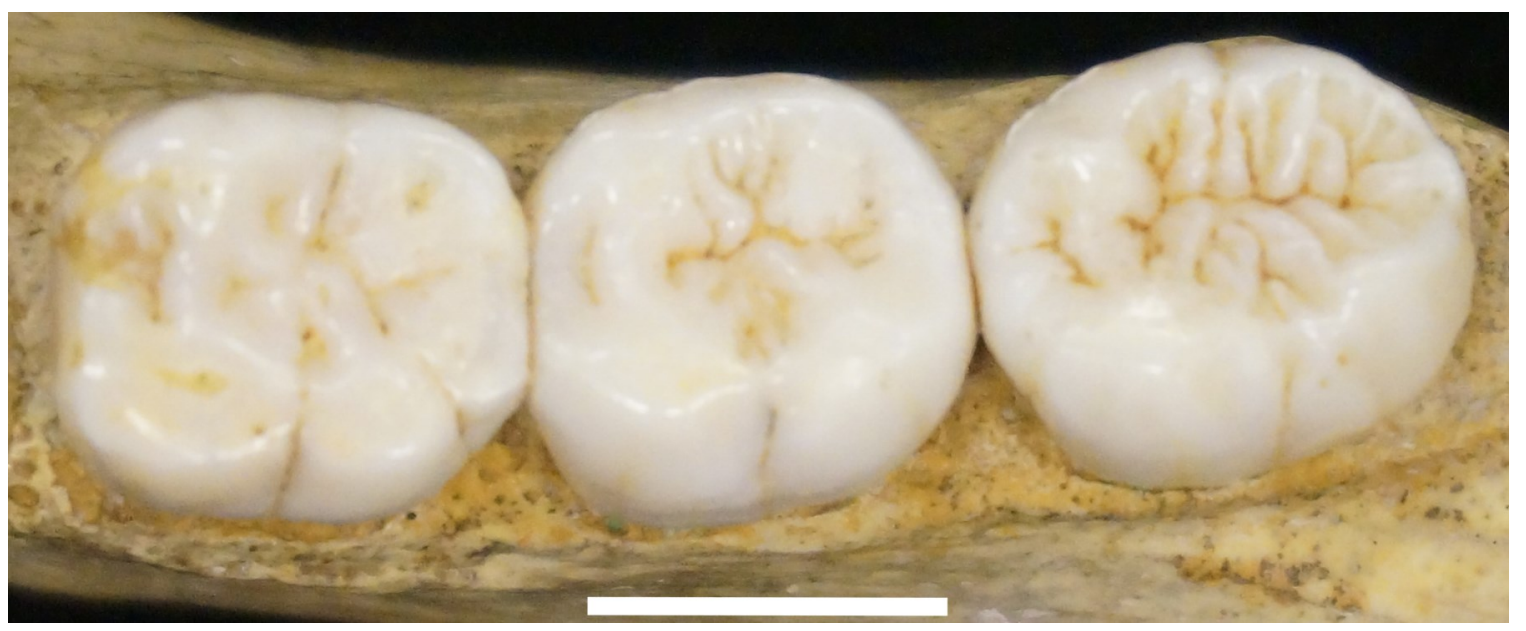

Figure 3. A well-developed, oblong anterior fovea can be observed on all left permanent molars $\left(\mathrm{M}_{1}, \mathrm{M}_{2}\right.$ and $\mathrm{M}_{3}$, from left to right) of Montmaurin, albeit its expression differs. Note the absence of the entoconulid and metaconulid (Cusps 6 and 7, respectively). 
within the buccal groove separating the protoconid and hypoconid (ASUDAS grade 1). There are a total of five cusps evident on the right deciduous second molar $\left(\mathrm{dm}_{2}\right)$, including a pronounced hypoconulid (ASUDAS grade 5). In addition, there is a large metaconulid with a free apex situated within the lingual groove that separates the metaconid and entoconid (ASUDAS grade 4) on the right second deciduous molar $\left(\mathrm{dm}_{2}\right)$.

\section{Roc de Marsal}

The relatively complete skeleton of the Roc de Marsal child, has been aged to approximately three years (Heim, 1976; Minugh-Purvis, 1988; Williams, 2013; Williams and Cofran, 2016). The deciduous dentition is fully erupted, and only minimal attrition characterizes the deciduous molars. The permanent first molar crowns ( $\mathrm{M}^{1}$ and $\left.\mathrm{M}_{1}\right)$ can be seen fully developed and embedded within the crypts.

On the right and left maxillary deciduous first molars $\left(\mathrm{dm}^{1}\right)$, wear facets are visible on the hypocone. There are four cusps on both the right and left deciduous first molars $\left(\mathrm{dm}^{1}\right)$. A large distal groove separates the metacone, which is rather small, but is represented as an independent cuspule (ASUDAS grade 2) (see Fig. 4) from the hypocone, which is poorly-developed (ASUDAS grade 1) on both deciduous first molar $\left(\mathrm{dm}^{1}\right)$ antimeres.

On the hypocone of the deciduous second molar $\left(\mathrm{dm}^{2}\right)$ a large wear facet is evident, stronger on the left than the right, and a deep cleft separates the hypocone and the trigone. There are five cusps evident on this dental element. These include a metacone, which is pronounced in size on the right (ASUDAS grade 5), but much smaller on the left antimere (ASUDAS grade 3). The hypocone on the second deciduous molar $\left(\mathrm{dm}^{2}\right)$ is larger on the left (ASUDAS grade 4) than on the right (ASUDAS grade 3). A weak metaconule exists on both deciduous second molars $\left(\mathrm{dm}^{2}\right)$, although, like the hypocone, it is larger on the left (ASUDAS grade 2) than on the right (ASUDAS grade 1). On the deciduous second molar $\left(\mathrm{dm}^{2}\right)$, a well-developed and independent Carabelli's cusp is evident (ASUDAS grade 7) on both sides (see Fig. 4).

Small wear facets exist on the buccal cusps of the mandibular deciduous first molars $\left(\mathrm{dm}_{1}\right)$, although they are deeper on the right than on the left. On the deciduous first molar $\left(\mathrm{dm}_{1}\right)$ an elongated and deep anterior fovea is present, bordered by a welldeveloped mesial ridge (ASUDAS grade 4) on right and left sides. On the right, the cusp number is four, whereas the left deciduous first molar $\left(\mathrm{dm}_{1}\right)$ presents five cusps.

Similar to the mandibular deciduous first molar $\left(\mathrm{dm}_{1}\right)$, small wear facets can be observed on the buc-

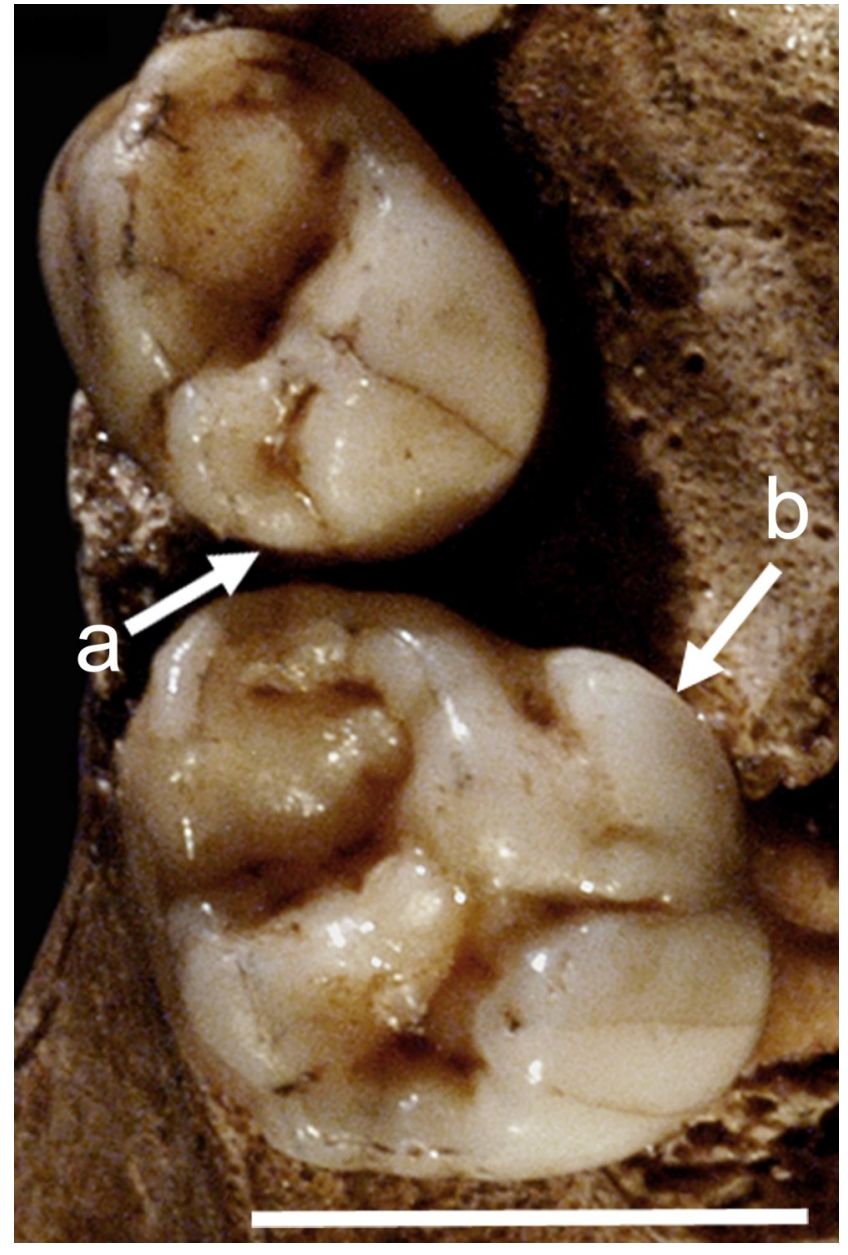

Figure 4. The Roc de Marsal right maxillary deciduous first and second molars $\left(\mathrm{dm}^{1}\right.$ and $\left.\mathrm{dm}^{2}\right)$ exhibit a number of traits, including a small hypocone (a) on the deciduous first molar $\left(\mathrm{dm}^{1}\right)$, and a pronounced Carabelli's cusp (b) on the deciduous second molar $\left(\mathrm{dm}^{2}\right)$.

cal cusps of the deciduous second molars $\left(\mathrm{dm}_{2}\right)$, although they are more extensive on the right than the left. The metaconid central ridge is deflected in a distal direction, although, it does not reach the entoconid (ASUDAS grade 2) on the left second deciduous molar $\left(\mathrm{dm}_{2}\right)$. On the right, the deflecting wrinkle is more weakly developed (ASUDAS grade 1). On the right deciduous second molar $\left(\mathrm{dm}_{2}\right)$, a protostylid can be observed as a full cusp, represented on the buccal surface of the protoconid as a buccal groove (ASUDAS grade 6). A hypoconulid exists on right and left deciduous second molars $\left(\mathrm{dm}_{2}\right)$. However, it is medium in size on the right (ASUDAS grade 3 ) and small on the left (ASUDAS grade 2). On the left deciduous second molar $\left(\mathrm{dm}_{2}\right)$, a small metaconulid can be observed (ASUDAS grade 2).

Scladina 1-4A

Scladina 1-4A comprises right and left demi- 
mandibles, a right maxillary fragment as well as 11 teeth from a single older child, aged to 8 to 11 years (Smith et al., 2007, 2014; Toussaint et al. 2011, 2014; Williams, 2013; Toussaint, 2014; Williams and Cofran, 2016). The deciduous teeth examined here include the right maxillary molars $\left(\mathrm{dm}^{1}\right.$ and $\left.\mathrm{dm}^{2}\right)$. Three permanent molars are also represented. These include the right maxillary second molar $\left(\mathrm{M}^{2}\right)$ and the right mandibular first and second molars $\left(\mathrm{M}_{1}\right.$ and $\mathrm{M}_{2}$ ). Scores for these teeth using the ASUDAS are reported by Toussaint (2014); the two sets of scores present more similarities than differences.

The right maxillary deciduous first molar $\left(\mathrm{dm}^{1}\right)$ of Scladina 4A-7 is substantially worn and exhibits a small metacone (ASUDAS grade 3) (Toussaint, 2014). The cusp number of the deciduous first molar $\left(\mathrm{dm}^{1}\right)$ is three. The right maxillary deciduous second molar $\left(\mathrm{dm}^{2}\right)$ of Scladina 4A-5 is moderately worn (Toussaint, 2014). Dentine exposures exist on the protocone and hypocone surfaces. The metacone is larger on the deciduous second molar $\left(\mathrm{dm}^{2}\right)$ (ASUDAS grade 4) than on $\mathrm{dm}^{1}$. The hypocone can be described as rather large (ASUDAS grade 4) (Toussaint, 2014).

The right maxillary permanent second molar $\left(\mathrm{M}^{2}\right)$ of Scladina 4A-3 is unerupted and the tooth crown is rectangular in shape (Toussaint, 2014). The paracone is large, and both the metacone and hypocone are present, although they differ in grade. Similar to the deciduous second molar $\left(\mathrm{dm}^{2}\right)$, the permanent second molar $\left(\mathrm{M}^{2}\right)$ has a well-developed metacone (ASUDAS grade 4), although the hypocone can be characterized as relatively smaller in size (ASUDAS grade 3). Between the hypocone and metacone of the permanent second molar $\left(\mathrm{M}^{2}\right)$, a metaconule can be observed, although it is small (ASUDAS grade 3). The protocone features a small " $Y$ " indentation on the lingual surface indicative of a rudimentary Carabelli's trait (ASUDAS grade 3).

The mandibular permanent first and second molars $\left(\mathrm{M}_{1}\right.$ and $\left.\mathrm{M}_{2}\right)$ of Scladina $4 \mathrm{~A}-1$ are associated with the right demi-mandible. There are wear facets present on the permanent first molar $\left(\mathrm{M}_{1}\right)$; wear is greatest on the protoconid, followed by the hypoconid. On the permanent first molar $\left(\mathrm{M}_{1}\right)$, a fovea exists within the buccal groove separating the protoconid and the hypoconid. However, it cannot be described as a true protostylid (ASUDAS grade 1). A hypoconulid can be observed, and is rather large (ASUDAS grade 4) (Toussaint, 2014).

The permanent second molar $\left(\mathrm{M}_{2}\right)$ is not fully erupted, and exhibits a complex occlusal morphology (Toussaint, 2014). A tall mesial ridge borders an elongated and deep anterior fovea on the permanent second molar $\left(\mathrm{M}_{2}\right)$ (ASUDAS grade 4$)$. The groove pattern indicative of the " + " configuration can be discerned. There are six cusps on the second molar $\left(\mathrm{M}_{2}\right)$, including a small hypoconulid (ASUDAS grade 2 ). The six cusps also include a tuberculum sextum, although it is substantially smaller than the hypoconulid (ASUDAS grade 1).

\section{ECOGEOGRPAHY}

There are a number of differences in dental morphology across geographic regions (Table 2). For example, in the Mediterranean (Hortus), the metacone and hypocone are larger on maxillary deciduous and permanent first molars $\left(\mathrm{dm}^{1}\right.$ and $\left.\mathrm{M}^{1}\right)$ than in the other regions. On the mandibular teeth, individuals from Hortus differ from Montmaurin of the Pyrenees in the expression of an anterior fovea, protostylid, entoconulid, and metaconulid on the permanent third molar $\left(\mathrm{M}_{3}\right)$. The presence of a metaconule on maxillary deciduous and permanent first molars $\left(\mathrm{dm}^{1}\right.$ and $\left.\mathrm{M}^{1}\right)$ is unique to the Meuse River Basin of Belgium, as is cusp number on the mandibular deciduous and permanent first molars ( $\mathrm{dm}_{1}$ and $\left.\mathrm{M}_{1}\right)$. The Pyrenees and Southwest France do not exhibit any dental traits that are lacking representation in the other ecogeographic regions (Table 2).

Dental traits that are expressed in all of the ecogeographic regions include the anterior fovea on the deciduous and permanent first molars $\left(\mathrm{dm}_{1}\right.$ and $\left.\mathrm{M}_{1}\right)$, which is found on a total of 16 teeth (Table 2). Additionally, a cusp number of $5+$ and the presence of a hypoconulid on the deciduous and permanent second molars $\left(\mathrm{dm}_{2}\right.$ and $\left.\mathrm{M}_{2}\right)$ are expressed in all ecogeographic regions (Table 2 ).

Dental traits that appear in the Mediterranean, Pyrenees, and the Meuse River Basin of Belgium, but not in Southwest France include the development of the protostylid and hypoconulid on the deciduous and permanent first molars $\left(\mathrm{dm}_{1}\right.$ and $\left.\mathrm{M}_{1}\right)$, and a pronounced anterior fovea on the deciduous and permanent second molars ( $\mathrm{dm}_{2}$ and $\left.\mathrm{M}_{2}\right)$ (Table 2$)$. The Pyrenees and Mediterranean sites share 11 traits in common, versus five traits shared between the Mediterranean and Southwest France. The Pyrenees and Southwest France share four traits in common (Table 2).

The dental traits that distinguish ecogeographic regions include the expression of the $\mathrm{M}^{1}$ hypocone and metaconule on the maxillary molars, and the entoconulid and metaconulid on mandibular molars. The expression of the metacone, anterior fovea, and mandibular molar cusp numbers are the most similar across ecogeographic regions.

\section{Chronology}

All of the dental features present in the older period 
Table 2. Dental trait comparison by ecogeographical region.

\begin{tabular}{|c|c|c|c|c|c|c|}
\hline Tooth type & Trait & Trait presence & $\begin{array}{c}\text { Mediterran- } \\
\text { ean }\end{array}$ & $\begin{array}{c}\text { Meuse River } \\
\text { Basin }\end{array}$ & Pyrenees & $\begin{array}{l}\begin{array}{l}\text { Southwest } \\
\text { France }\end{array} \\
\end{array}$ \\
\hline \multirow{3}{*}{$\begin{array}{c}\mathrm{dm}^{1} \& \mathrm{M}^{1} \\
(\mathrm{n}=7)\end{array}$} & Cusp number & Score 5+ & & present $(n=1)$ & & \\
\hline & Metacone & Score 4-5 & present $(n=1)$ & & & \\
\hline & Hypocone & Score 4-5 & present $(\mathrm{n}=1)$ & & & \\
\hline \multirow{5}{*}{$\begin{array}{c}\mathrm{dm}^{2} \& \mathrm{M}^{2} \\
(\mathrm{n}=7)\end{array}$} & Cusp number & Score 4+ & & present $(n=1)$ & & present $(n=4)$ \\
\hline & Metacone & Score 4-5 & & present $(n=3)$ & & present $(n=3)$ \\
\hline & Hypocone & Score 2-5 & & present $(n=3)$ & & present $(n=4)$ \\
\hline & Carabelli & Score 5-7 & & present $(\mathrm{n}=1)$ & & present $(n=4)$ \\
\hline & Cusp 5 & Score $1-5$ & & present $(n=1)$ & & present $(n=4)$ \\
\hline \multirow{7}{*}{$\begin{array}{c}\mathrm{dm}_{1} \& \mathrm{M}_{1} \\
(\mathrm{n}=16)\end{array}$} & Anterior fovea & Score $2-4$ & present $(n=2)$ & present $(n=1)$ & present $(n=2)$ & present $(n=3)$ \\
\hline & Cusp number & Score 6+ & & present $(n=1)$ & & \\
\hline & $\begin{array}{l}\text { Mid-trigonid } \\
\text { crest }\end{array}$ & Score 1 & & present $(n=1)$ & present $(n=3)$ & \\
\hline & Protostylid & Score 1-7 & present $(n=1)$ & present $(n=2)$ & present $(n=1)$ & \\
\hline & Cusp 5 & Score 3-5 & present $(n=3)$ & present $(n=1)$ & present $(n=3)$ & \\
\hline & Cusp 6 & Score 1-5 & & present $(n=1)$ & & \\
\hline & Cusp 7 & Score 1-4 & present $(n=3)$ & present $(n=1)$ & & \\
\hline \multirow{7}{*}{$\begin{array}{c}\mathrm{dm}_{2} \& \mathrm{M}_{2} \\
(\mathrm{n}=11)\end{array}$} & Anterior fovea & Score $2-4$ & present $(n=2)$ & present $(n=2)$ & present $(n=2)$ & \\
\hline & Cusp number & Score 5+ & present $(n=2)$ & present $(n=2)$ & present $(n=1)$ & present $(\mathrm{n}=1)$ \\
\hline & $\begin{array}{l}\text { Mid-trigonid } \\
\text { crest }\end{array}$ & Score 1 & present $(\mathrm{n}=2)$ & & present $(n=2)$ & \\
\hline & Protostylid & Score 1-7 & present $(n=1)$ & & present $(n=1)$ & present $(n=2)$ \\
\hline & Cusp 5 & Score 1-5 & present $(n=2)$ & present $(n=2)$ & present $(\mathrm{n}=1)$ & present $(n=3)$ \\
\hline & Cusp 6 & Score 1-5 & present $(n=2)$ & present $(n=1)$ & & \\
\hline & Cusp 7 & Score 1-4 & present $(n=4)$ & present $(n=1)$ & & present $(n=2)$ \\
\hline \multirow[t]{7}{*}{$\mathrm{M}_{3}(\mathrm{n}=5)$} & Anterior fovea & Score 2-4 & present $(n=3)$ & & & \\
\hline & Cusp number & Score 5+ & present $(n=3)$ & & present $(n=1)$ & \\
\hline & $\begin{array}{l}\text { Mid-trigonid } \\
\text { crest }\end{array}$ & Score 1 & present $(\mathrm{n}=1)$ & & present $(\mathrm{n}=1)$ & \\
\hline & Protostylid & Score 1-7 & present $(n=1)$ & & & \\
\hline & Cusp 5 & Score 1-5 & present $(n=3)$ & & present $(n=1)$ & \\
\hline & Cusp 6 & Score 1-5 & present $(n=3)$ & & & \\
\hline & Cusp 7 & Score 1-4 & present $(n=2)$ & & & \\
\hline
\end{tabular}


are also found in the younger one, with the exception of the Hortus assemblage which lacks Carabelli's trait where it could be observed (Hortus VIII) (Table 3), corroborating de Lumley (1973). Dental features that are present in late MIS 4 and MIS 3, but absent in Scladina 1-4A, include the presence of a metaconule and a pronounced expression of the hypocone and metacone. On the maxillary deciduous and permanent second molars $\left(\mathrm{dm}^{2}\right.$ and $\left.\mathrm{M}^{2}\right)$, Scladina 1-4A lacks a cusp number of $4+$ and a welldeveloped Carabelli's feature, as noted by Toussaint (2014). The older time period also lacks more than five cusps on mandibular deciduous and permanent first molars ( $\mathrm{dm}_{1}$ and $\left.\mathrm{M}_{1}\right)$, and on the mandibular deciduous and permanent second molars ( $\mathrm{dm}_{2}$ and
$\mathrm{M}_{2}$ ), a metaconulid is not observed. On the third mo$\operatorname{lar}\left(\mathrm{M}_{3}\right)$, Montmaurin of the older period differs from the younger Hortus remains, by lacking a pronounced anterior fovea, and any expression whatsoever of a protostylid, entoconulid, and metaconulid (Table 3).

On the maxillary molars, no obvious difference is found between older and younger periods, with the possible exception of Carabelli's trait (Table 3). The dental features which may differentiate these broad chronological categories of older and younger include the expression of the hypoconulid, the entoconulid, and metaconulid (Table 3). The dental traits that are the most similar across chronological periods include the expression of the anterior fovea and

Table 3. Dental trait comparison by site chronology.

\begin{tabular}{|c|c|c|c|c|}
\hline Tooth type & Trait & Trait presence & Older & Younger \\
\hline \multirow[t]{3}{*}{$\mathrm{dm}^{1} \& \mathrm{M}^{1}(\mathrm{n}=7)$} & Cusp number & Score 5+ & & present $(\mathrm{n}=1)$ \\
\hline & Metacone & Score 4-5 & & present $(n=1)$ \\
\hline & Hypocone & Score $4-5$ & & present $(n=1)$ \\
\hline \multirow[t]{5}{*}{$\mathrm{dm}^{2} \& \mathrm{M}^{2}(\mathrm{n}=7)$} & Cusp number & Score $4+$ & & present $(n=5)$ \\
\hline & Metacone & Score 4-5 & present $(n=2)$ & present $(n=4)$ \\
\hline & Hypocone & Score $2-5$ & present $(n=2)$ & present $(\mathrm{n}=5)$ \\
\hline & Carabelli & Score 5-7 & & present $(n=5)$ \\
\hline & Cusp 5 & Score $1-5$ & present $(n=1)$ & present $(n=4)$ \\
\hline \multirow[t]{7}{*}{$\mathrm{dm}_{1} \& \mathrm{M}_{1}(\mathrm{n}=16)$} & Anterior fovea & Score $2-4$ & present $(n=2)$ & present $(n=6)$ \\
\hline & Cusp number & Score $6+$ & & present $(n=1)$ \\
\hline & Mid-trigonid crest & Score 1 & present $(n=3)$ & present $(n=1)$ \\
\hline & Protostylid & Score $1-7$ & present $(n=2)$ & present $(n=2)$ \\
\hline & Cusp 5 & Score 3-5 & present $(\mathrm{n}=4)$ & present $(n=3)$ \\
\hline & Cusp 6 & Score $1-5$ & & present $(n=1)$ \\
\hline & Cusp 7 & Score 1-4 & & present $(n=4)$ \\
\hline \multirow[t]{7}{*}{$\mathrm{dm}_{2} \& \mathrm{M}_{2}(\mathrm{n}=11)$} & Anterior fovea & Score 2-4 & present $(n=3)$ & present $(n=3)$ \\
\hline & Cusp number & Score $5+$ & present $(n=2)$ & present $(n=4)$ \\
\hline & Mid-trigonid crest & Score 1 & present $(n=2)$ & present $(n=2)$ \\
\hline & Protostylid & Score 1-7 & present $(n=1)$ & present $(n=3)$ \\
\hline & Cusp 5 & Score $1-5$ & present $(n=2)$ & present $(n=6)$ \\
\hline & Cusp 6 & Score $1-5$ & present $(n=1)$ & present $(n=2)$ \\
\hline & Cusp 7 & Score $1-4$ & & present $(n=7)$ \\
\hline \multirow[t]{7}{*}{$M_{3}(n=5)$} & Anterior fovea & Score 2-4 & & present $(n=3)$ \\
\hline & Cusp number & Score $5+$ & present $(n=1)$ & present $(n=3)$ \\
\hline & Mid-trigonid crest & Score 1 & present $(n=1)$ & present $(\mathrm{n}=1)$ \\
\hline & Protostylid & Score 1-7 & & present $(n=1)$ \\
\hline & Cusp 5 & Score 1-5 & present $(n=1)$ & present $(n=3)$ \\
\hline & Cusp 6 & Score $1-5$ & & present $(n=3)$ \\
\hline & Cusp 7 & Score 1-4 & & present $(n=2)$ \\
\hline
\end{tabular}


protostylid on the mandibular molars, and cusp number and hypocone size on the maxillary first molars (Table 3).

\section{Anterior fovea}

\section{DISCUSSION}

The anterior fovea appears with near ubiquity in the Neanderthals (Bailey, 2006), and other Pleistocene humans (Hrdlička, 1924; Turner et al., 1991). However, variation is also observed. For example, the anterior fovea is not as deep or distinct in Hortus II as is observed on Montmaurin and Malarnaud. Additionally, the anterior fovea of the first and second molars $\left(\mathrm{M}_{1}\right.$ and $\left.\mathrm{M}_{2}\right)$ of Montmaurin is smaller than that observed on the first molar $\left(\mathrm{M}_{1}\right)$ of Malarnaud. It is prominent on the deciduous first molars $\left(\mathrm{dm}_{1}\right)$ of Pech de l'Azé 1 and Roc de Marsal. Bailey (2006) notes an inter-correlation between the presence of an anterior fovea and the mid-trigonid crest. This relationship was noted in some individuals, such as Hortus IV, Hortus V, and Montmaurin, but not others (Table 2).

\section{Entoconulid and metaconulid}

The entoconulid and metaconulid, also known as Cusp 6 and Cusp 7, respectively, are routinely absent in the Pyrenees sample, whereas these accessory cusps are present in the Meuse River Basin of Belgium category (Table 2). Although the entoconulid is absent in the individuals from Southwest France, the metaconulid is present. Both of these cusps are found in Hortus for the second molars $\left(\mathrm{M}_{2}\right)$; on the first molars $\left(\mathrm{M}_{1}\right)$, only the metaconulid can be observed. Bailey (2006) observes rather low frequencies of Cusp 6 and Cusp 7 (20-40\%), with the exception of the entoconulid in the second and third molars $\left(\mathrm{M}_{2}\right.$ and $\mathrm{M}_{3}$ ), which approaches $50 \%$. In this study, the metaconulid occurs more often than does the entoconulid.

\section{Hypocone}

The hypocone of the maxillary first molars $\left(\mathrm{dm}^{1}\right.$ and $\mathrm{M}^{1}$ ) differentiates the ecogeographic groupings (Table 3). This contrast is based primarily on the reduced expression of this feature in Southwest France (Pech de l'Azé 1 and Roc de Marsal) and the Meuse River Basin of Belgium (Engis 2) contrasting to the enlarged $\left(\mathrm{M}^{1}\right)$ hypocone in Hortus VIII. Southwest France and the Meuse River Basin of Belgium are aligned in other features that suggest more similarity than expected from such distant locations. Bailey (2006) notes that the hypocone is usually present and enlarged in Neanderthals. This is certainly true of Hortus VIII who expresses a large hypocone (Lumley, 1973), but not the deciduous molars of this study.

\section{Carabelli's cusp}

Carabelli's trait is noted often in this study, particularly on the deciduous second molars where its strongest expression is observed. Bailey (2006) finds that it also occurrs relatively consistently in Neanderthals in both first (68\%) and second molars (50\%), corroborating the observations noted for Southwest France and the Meuse River Basin of Belgium, but not in Hortus (Table 2).

\section{Additional considerations}

Zubov (1992) reports a prevalence of the midtrigonid crest (epicristid) on Neanderthal mandibular molars. Only in the Pyrenees is there a consistent presence of this dental trait across the molar row; although, it is also noted in the Meuse River Basin of Belgium (see Table 2). However, it appears to be Engis 2, presumably from the younger MIS 3, rather than Scladina 1-4A (MIS 5), which exhibits a midtrigonid crest.

Bailey (2006) reports the expression of at least five cusps on the molars is nearly ubiquitous in $\mathrm{Ne}$ anderthals, an observation corroborated in this study (Table 2). The rarity of the expression of a deflecting wrinkle in Neanderthals (Bailey, 2006) is supported here as it is present only in Hortus II, Malarnaud, and Roc de Marsal. In addition, the "Y" groove pattern for $\mathrm{M}_{1}$ is relatively widespread in Neanderthals as reported in Bailey (2006), and is found in Engis 2, Hortus II, Scladina 1-4A, and Montmaurin. Bailey (2006) suggests the " $X$ " groove pattern for $\mathrm{M}_{2}$ is relatively common, which in this study is expressed in Hortus IV and Montmaurin.

It is evident that the Meuse River Basin of Belgium is not distinct (Table 2), at least in the younger time period, as it shares several traits in common with Neanderthals from Southwest France. The two sites closest in proximity (Mediterranean and Pyrenees) are not the most similar, suggesting ecogeographic distance fails to account for all the differences among regions. The fact that all of the traits examined are represented in the younger category (Table 3) suggests that chronology does explain some of the variation, at least for mandibular traits, although a greater number of individuals are included in the younger category. For the maxillary molars, only Carabelli's trait differentiates the older/ younger categories (Table 3 ).

\section{CONCLUSIONS}

The expression of the anterior fovea is common in Neanderthals (Lumley, 1973; Bailey, 2000, 2006). It is often found on mandibular deciduous and permanent molar rows, and its presence on $\mathrm{M}_{1}$ increases 
the chance that it will be present on both $\mathrm{M}_{2}$ and $\mathrm{M}_{3}$ (Fig. 3). The anterior fovea is expressed on deciduous mandibular molars, such as in Pech de l'Azé 1, Roc de Marsal, and Engis 2, as is a prominent Carabelli's cusp. Other features such as the expression of the entoconulid and metaconulid are found on the permanent molars in the Hortus assemblage and in Engis 2, but not in the Pyrenees. Maxillary molar hypocone size and the presence of a metaconule differ between Mediterranean Hortus VIII on the one hand, and Southwest France and the Meuse River Basin of Belgium on the other. Montmaurin and Malarnaud from the Pyrenees region resemble one another in the expression of traits on mandibular $\mathrm{M}_{1}$ and are dissimilar to Scladina 1-4A. Likewise, Hortus II and Hortus IV resemble one another, although Hortus II and Hortus V are younger (Phase V) than Hortus IV (Phase IV) (Lumley, 1973). However, they are not identical, and Hortus IV and Hortus V also share traits to the exclusion of Hortus II, suggesting ecogeography alone does not account for the variation in the expression of dental features. Chronology may account for the absence in MIS 7 to 5 of $6+$ cusps in mandibular molars, the expression of a well -developed entoconulid and metaconulid, and a pronounced Carabelli's feature, all of which are observed in late MIS 4/MIS 3.

\section{ACKNOWLEDGMENTS}

It is with much gratitude that the following curators are thanked for their permission to examine the Neanderthal fossils featured here: Aurélie Fort and Liliana Huet, Musée de l'Homme; Marie-Antoinette de Lumley, Gaël Becam, and Tony Chevalier, Centre Européen de Recherches Préhistoriques de Tautavel; Jean-Jacques Cleyet-Merle, Musée National de Préhistoire Les Eyzies-de-Tayac; Valentin Fischer, Université de Liège, and Dominique Bonjean and Michel Toussaint, Scladina Cave Archaeological Centre. The image utilized in Figure 4 featuring Roc de Marsal belongs to the collections of the Musée National de Préhistoire, les Eyzies, Dordogne, France, and was used with the permission of Jean-Jacques CleyetMerle. Funding for this project was received by Fulbright-Belgium and the Commission for Educational Exchange between the United States, Belgium, and Luxembourg.

\section{LITERATURE CITED}

Bailey S.E. (2000). Dental morphological affinities among late Pleistocene and recent humans. Dental Anthropology, 14, 1-8.

Bailey S.E. (2002). A closer look at Neanderthal postcanine dental morphology. I. The mandibular dentition. Anatomical Record, 269, 148-156.

Bailey S.E. (2004). A morphometric analysis of max- illary molar crowns of Middle-Late Pleistocene hominins. Journal of Human Evolution, 47, 183198.

Bailey S.E. (2006). Beyond shovel-shaped incisors: Neandertal dental morphology in a comparative context. Periodicum Biologorum, 108, 253-267.

Crégut-Bonnoure É., Boulbes N., Guérin C., Pernaud J., Tavoso A., Cammas R. (2010). Le contexte géomorphologique et faunique de l'homme de Montmaurin (Haute-Garonne). Préhistoires Méditerranéennes, 1, 35-85.

Di Modica K., Toussaint M., Abrams G., Pirson S. (2016). The Middle Palaeolithic from Belgium: chronostratigraphy, territorial management and culture on a mosaic of contrasting environments. Quaternary International, 411, 77-106.

Guérin G., Discamps E., Lahaye C., Mercier N., Guibert P., Turq A., Dibble H.L., McPherron S.P., Sandgathe D., Goldberg P., Jain M., Thomsen K., Patou-Mathis M., Castel J.-C., Soulier M.-C. (2012). Multi-method (TL and OSL), multimaterial (quartz and flint) dating of the Mousterian site of Roc de Marsal (Dordogne, France): correlating Neanderthal occupations with the climatic variability of MIS 5-3. Journal of Archaeological Sciences, 39, 3071-3084.

Hanihara K. (1961). Criteria for classification of crown characters of the human deciduous dentition. Journal of the Anthropological Society of Nipon, $69,27-45$.

Heim J.-L. (1976). Les Néandertaliens en Périgord. In H. de Lumley (Ed.), La préhistoire Française. Tome I: Les civilisations Paléolithiques et Mésolithiques de la France (pp. 578-583). Paris: Éditions du CNRS.

Hrdlička A. (1924). New data on the teeth of early man and certain fossil European apes. American Journal of Physical Anthropology, 3, 109-132.

Hublin J.-J., Roebroeks W. (2009). Ebb and flow or regional extinctions? On the character of Neandertal occupation of northern environments. Comptes Rendus Palevol, 8, 503-509.

Hublin J.-J., Bailey S., Olejniczak A., Smith T., Verna C., Sbihi-Alaoui F.Z., Zouak M. (2012). Dental evidence from the Aterian human populations of Morocco. In J.-J. Hublin \& S. McPherron (Eds.), Modern origins: A North African perspective (pp. 189-204). Dordrecht: Springer.

Kelso J., Prüfer K. (2014). Ancient humans and the origin of modern humans. Current Opinion in Genetics and Development, 29, 133-138.

Lalueza-Fox C., Rosas A., Estalrrich A., Gigli E., Campos P.F., García-Tabernero A., GarcíaVargas S., Sánchez-Quinto F., Ramírez O., Civit S., Bastir M., Hugnet R., Santamaría D., Gilbert M.T.P., Willerslav E., de la Rasilla M. (2011). Ge- 
netic evidence for patrilocal mating behavior among Neandertal groups. Proceedings of the $\mathrm{Na}$ tional Academy of Sciences USA, 108, 250-253.

Lumley M.-A. de. (1973). Anténéandertaliens et Néandertaliens du bassin méditerranéen occidental européen. Marseille: Université de Provence.

Lumley M.-A. de. (1976). Les Néandertaliens dans le Midi méditerranéen. In H. de Lumley (Ed.), La préhistoire Française. Tome I: Les civilisations Paléolithiques et Mésolithiques de la France (pp. 567577). Paris: Éditions du CNRS.

Minugh-Purvis N. (1988). Patterns of craniofacial growth and development in Upper Pleistocene hominids. (Ph.D. dissertation), University of Pennsylvania, Philadelphia, PA.

Patte E. (1959). La dentition des Néandertaliens. Annales de Paléontologie, 45, 1-162.

Petite-Marie N., Ferebach D., Bouvier J.-M., Vandermeersch B. (1971). France. In K.P. Oakey, B.G. Campbell \& T.I. Molleson (Eds.), Catalogue of fossil hominids. Part II: Europe (pp. 71-187). London: Trustees of the British Museum (Natural History).

Pirson S., Court-Picon M., Dambon F., Balescu S., Bonjean D., Laesarts P. (2014). The palaeoenvironmental context and chronostratigraphic framework of the Scladina Cave sedimentary sequence (Units 5 to 3 sup). In M. Toussaint \& D. Bonjean (Eds.), The Scladina 1-4A juvenile Neandertal (Andenne, Belgium): Palaeoanthropology and context (pp. 69-92.). Andenne, Belgium: Études et Recherches Archéologiques de l'Université de Liège.

Semal P., Toussaint M., Maureille B., Rougier H., Crevecoeur I., Balzeau A., Bouchneb L., Louryan S., De Clerck N., Rausin L. (2005). Numérisation des restes humains néandertaliens belges. Préservation patrimoniale et exploitation scientifique. Notae Praehistoricae, 25, 25-38.

Semal P., Rougier H., Crevecoeur I., Jungels C., Flas D., Hauzeur A., Maureille B., Germonpré M., Bocherens H., Pirson S., Cammaert L., De Clerk N., Hambucken A., Higman T., Toussaint M., van der Plicht J. (2009). New data on the late Neandertals: direct dating of the Belgian Spy fossils. American Journal of Physical Anthropology, 138, 421 $-428$.

Smith T.M., Toussaint M., Reid D.J., Olejniczak A.J., Hublin J.-J. (2007). Rapid dental development in a Middle Paleolithic Belgian Neanderthal. Proceedings of the National Academy of Sciences USA, 104, 20220-20225.

Smith T.M., Reid D.J., Olejniczak A.J., Tafforeau P.T., Hublin J.-J., Toussaint M. (2014). Dental development in and age at death of the Scaldina 1-4A juvenile Neandertal. In M. Toussaint \& D. Bonjean (Eds.), The Scladina 1-4A juvenile Nean- dertal (Andenne, Belgium): Palaeoanthropology and context (pp. 155-166). Andenne, Belgium: Études et Recherches Archéologiques de l'Université de Liège.

Soressi M., Jones H.L., Rink W.J., Maureille B., Tillier A.-M. (2007). The Pech-de-l' Azé I Neandertal child: ESR, uranium series and AMS 14C dating of its MTA type B context. Journal of Human Evolution, 52, 455-466.

Tillier A.-M. (1983). Le crâne d'enfant d'Engis 2: un exemple de distribution des caractrès juvéniles, primitifs et néandertaliens. Bulletin Société royale belge d'Anthropologie et de Préhistoire, 94, 51-75.

Toussaint M. (2014). The dentition of the Scladina 1$4 A$ juvenile Neandertal. In M. Toussaint \& D. Bonjean (Eds.), The Scladina 1-4A juvenile Neandertal (Andenne, Belgium): Palaeoanthropology and context (pp. 233-306). Andenne, Belgium: Études et Recherches Archéologiques de l'Université de Liège.

Toussaint M., Semal P., Pirson S. (2011). Les Néandertaliens du bassin mosan belge: bilan 20062011. In M. Toussaint, K. Di Modica \& S. Pirson (Eds.), Le Paléolithique moyen de Belgique. Mélanges Marguerite Ulrix-Closset (pp. 149-196). Liège: Etudes et Recherches archéologiques de l'Université de Liège, 128, Les Chercheurs de la Wallonie. Hors-série 4.

Toussaint M., Bonjean D., Pirson S. (2014). The Scladina 1-4A juvenile Neandertal: a synthesis. In M. Toussaint \& D. Bonjean (Eds.), The Scladina 1-4A juvenile Neandertal (Andenne, Belgium): Palaeoanthropology and context (pp. 409-418). Andenne, Belgium: Études et Recherches Archéologiques de l'Université de Liège.

Turner C., Nichol C., Scott G. (1991). Scoring procedures for key morphological traits of the permanent dentition: The Arizona State University Dental Anthropology System. In M. Kelley \& C. Larsen (Eds.), Advances in Dental Anthropology (pp. 13-31). New York: Wiley Liss.

Twiesselmann F. (1971). Belgium. In K.P. Oakey, B.G. Campbell \& T.I. Molleson (Eds.), Catalogue of fossil hominids. Part II: Europe (pp. 5-13). London: Trustees of the British Museum (Natural History).

Williams F.L. (2013). Neandertal craniofacial growth and development and its relevance for modern human origins. In F. Smith F \& J. Ahern (Eds.), The origins of modern humans: Biology reconsidered (pp. 253-284). Hoboken, NJ: Wiley.

Williams FL, Cofran Z. (2016). Postnatal craniofacial ontogeny in Neandertals and modern humans. American Journal of Physical Anthropology, 159, 394 -409 .

Zubov A.A. (1992). The epicristid or middle trigonid crest defined. Dental Anthropology. Newsletter, 6, 9 